\title{
Emerging Technologies in Scar Management: The Role of Allogeneic Cells
}

Clarisse Ganier and Sonia Gaucher

\section{Contents}

51.1 Background -452

51.2 Allogenic Cell Therapy Studied in Scar Management Field - 452

51.3 Human Allogeneic Epidermal Sheets - 452

51.4 Cellular Dermal Substitutes and Human Dermal Fibroblasts Therapy -452

51.5 Human Skin Equivalent - 453

51.6 Bioprinting of Skin -453

51.7 Injections of Mesenchymal Stromal Cells (MSCs) for Skin Regeneration - 453

51.8 Promising Embryonic(-Like) Stem Cells Therapy for Scar Treatment - 454

51.9 Conclusion/Discussion -454

References -455 


\subsection{Background}

After skin injury, the wound-healing process has to occur as soon as possible to prevent excessive blood loss and/ or infection. In chronic wounds, this normal healing process fails, which results in a pathologic cycle of inflammation and protease release, leading to the development of a pathologic scar. Also, in the healing of large and deep wounds, scar formation is evident. Nevertheless, in some natural cases, such as fetal skin, humans and animals are able to heal scarless due to the fast wound-healing process and/or specific fetal characteristics [1].

Scars caused by burns, chronic ulcers from diabetes, infections, skin cancer surgery, and other genetic or somatic disease could require effective treatment to avoid functional and psychological troubles and even in some severe cases to prevent mortality. Most of the current treatments do not prevent scarring. They first aim to reduce local inflammation.

Herein, we will discuss about emerging technologies in scar management using allogeneic cell therapy. Allogeneic cell transplants offer the possibility of large prefabrication, cryopreservation for instantaneous use, and repeated applications. They also allow the use of fetal cells that show interesting properties. Furthermore, they are applicable for genetic skin diseases inducing severe scars such as dystrophic epidermolysis bullosa. Current research exploring allogeneic cell therapies for scar treatment show that they are mostly locally delivered by grafting and/or by intradermal injections.

\subsection{Allogenic Cell Therapy Studied in Scar Management Field}

Allogeneic cell therapies combined with scaffolding biomaterials have been employed in tissue engineering approaches for wound care and scar management. We will describe here the cells and their scaffold used in scar management. The common cell types used for scar treatments are fibroblasts and keratinocytes as commercial products for skin regeneration (- Table 51.1). The emergence of three-dimensional (3D) printing is gaining commercial interest for large-scale production. Research works on mesenchymal stromal cells (MSCs) therapy for scar management are also increasing and show very promising results.

\subsection{Human Allogeneic Epidermal Sheets}

Epidermal sheets consist of human keratinocytes that are differentiated in vitro to give rise to a stratified epidermal layer. They can be combined with other biocompatible substrates (bovine collagen, hyaluronic acid), acellular natural human or porcine materials, or nylon

\begin{tabular}{|c|c|c|}
\hline Source & $\begin{array}{l}\text { Commercial products and } \\
\text { their applications }\end{array}$ & $\begin{array}{l}\text { Type of } \\
\text { allogeneic cells }\end{array}$ \\
\hline \multirow[t]{2}{*}{ Skin } & $\begin{array}{l}\text { Apligraf }{ }^{\circledR} \\
\text { - Venous leg ulcers } \\
\text { - Diabetic foot ulcers } \\
\text { OrCel }{ }^{\circledR} \\
\text { - Partial-thickness burns } \\
\text { Clinical trials }\end{array}$ & $\begin{array}{l}\text { Living } \\
\text { fibroblasts and } \\
\text { keratinocytes }\end{array}$ \\
\hline & $\begin{array}{l}\text { TheraSkin }{ }^{\circledR} \\
\text { - Diabetic foot } \\
\text { - Venous leg ulcers } \\
\text { Cryoskin }{ }^{\circledR} \\
\text { - Chronic nonhealing } \\
\text { - Neuropathic diabetic } \\
\text { ulcers }\end{array}$ & Keratinocytes \\
\hline \multirow[t]{3}{*}{$\begin{array}{l}\text { Neonatal } \\
\text { foreskin }\end{array}$} & $\begin{array}{l}\text { TransCyte }{ }^{\circledR} \\
\text { - Full-thickness and deep } \\
\text { partial-thickness burns } \\
\text { - Partial-thickness burns }\end{array}$ & $\begin{array}{l}\text { Dead } \\
\text { fibroblasts }\end{array}$ \\
\hline & $\begin{array}{l}\text { Dermagraft }{ }^{\circledR} \\
\text { - Full-thickness diabetic } \\
\text { foot ulcers }\end{array}$ & $\begin{array}{l}\text { Living } \\
\text { fibroblasts }\end{array}$ \\
\hline & $\begin{array}{l}\text { Lyphoderm }{ }^{\circledR} \\
\text { - Chronic venous ulcer } \\
\text { - Partial-thickness burns }\end{array}$ & Keratinocytes \\
\hline Fetus & $\begin{array}{l}\text { Studied in animal models } \\
\text { or involved in clinical trials }\end{array}$ & $\begin{array}{l}\text { Fibroblasts } \\
\text { and/or } \\
\text { keratinocytes }\end{array}$ \\
\hline $\begin{array}{l}\text { Bone } \\
\text { marrow }\end{array}$ & $\begin{array}{l}\text { Studied in animal models } \\
\text { or involved in clinical trials }\end{array}$ & \multirow[t]{3}{*}{$\begin{array}{l}\text { Mesenchymal } \\
\text { stromal cells }\end{array}$} \\
\hline $\begin{array}{l}\text { Umbilical } \\
\text { cord }\end{array}$ & $\begin{array}{l}\text { Studied in animal models } \\
\text { or involved in clinical trials }\end{array}$ & \\
\hline $\begin{array}{l}\text { Adipose } \\
\text { tissue }\end{array}$ & $\begin{array}{l}\text { Studied in animal models } \\
\text { or involved in clinical trials }\end{array}$ & \\
\hline
\end{tabular}

or polyglactin meshes. An example of one product using allogeneic keratinocytes is Cryoskin ${ }^{\circledR}$ that is available from frozen cells on a carrier dressing [2]. A single blind study shows the efficacy of this cell therapy for the acceleration of healing of chronic nonhealing neuropathic diabetic ulcers. In general, the clinical outcome of the epidermal sheet grafts is usually not satisfying because of the nonpermanent character, ultimate rejection, and absence of a dermal component.

\subsection{Cellular Dermal Substitutes and Human Dermal Fibroblasts Therapy}

In contrast to epidermal sheets, the dermal substitutes are composed either of autologous or of allogeneic dermal fibroblasts. The scaffold for the cells consists mostly 
of biomaterials, like benzyl-esterified derivatives of hyaluronic acid (Hyaff-11), polyglycolic acid, or polyglactin. TransCyte ${ }^{\circledR}$ is a comparable product containing a nylon mesh coated with porcine dermal collagen that is seeded with neonatal fibroblasts and fixed to an outer silicone membrane.

The major indication of application consists in transient wound cover after surgery. One of the most

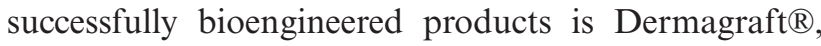
an allogeneic cell culture using neonatal dermal fibroblast grown on a biodegradable scaffold. This product showed the capacity to secrete several growth factors, to stimulate angiogenesis, and re-epithelialization from the wound edge, even after cryopreservation and thawing. In diabetic foot ulcers, its efficacy and its safety were demonstrated [2].

In addition, some other clinical trials are ongoing using a medicinal product comprised of viable allogeneic dermal fibroblasts suspended in HypoThermosol®FRS for remodeling scar contractures from burn patients and from dystrophic epidermolysis bullosa patients. Fibroblasts are from neonatal foreskin, cryopreserved, thawed, and expanded in culture under good manufacturing practice at Intercytex Ltd., UK ( ClinicalTrials.gov, Identifier: NCT01564407 [burn patients], ISRCTN67757229 [recessive dystrophic epidermolysis bullosa patients]).

\subsection{Human Skin Equivalent}

Skin equivalent is only composed of a culture of keratinocytes growing on dermal substitutes containing fibroblasts. An example of an allogeneic skin equivalent product is Apligraf ${ }^{\circledR}$ consisting of cultured keratinocytes on a dermal layer of fibroblasts within a bovine type 1 collagen matrix ( $\triangleright$ http://www.apligraf.com/ professional/). Apligraf ${ }^{\circledR}$ obtained its Food and Drug Administration (FDA) approval for diabetic foot ulcers and venous leg ulcers applications. This product has been well tolerated in over 150,000 patient applications.

Clinical trials showed that the healing rate of the venous ulcers treated with Apligraf ${ }^{\circledR}$ as well as the healing time was improved. Healing occurs with less fibrosis, which might be because of the construction of the graft itself containing neonatal cells and growth factors/ cytokines, stimulating a more fetal-like scarless wound healing. Another product used in clinical trials for the treatment of venous ulcers is $\mathrm{OrCel}{ }^{\circledR}$, a bilayered cellular matrix containing adult epidermal keratinocytes and dermal fibroblasts. Donor dermal fibroblasts are cultured within the porous Type I bovine collagen sponge while keratinocytes, from the same donor, are cultured on the coated, nonporous side of the collagen matrix.

Recently, OrCel ${ }^{\circledR}$ obtained its first FDA approvals for treatment of acute surgical excisions, such as contrac- ture release sites in patients suffering from dystrophic epidermolysis bullosa undergoing hand reconstruction surgery ( https://www.accessdata.fda.gov/cdrh_docs/ pdf/p010016b.pdf) and also in burn patients undergoing excision and grafting [2]. In vitro skin cells used to make OrCel® skin equivalent are extensively expanded that give rise to a low human leukocyte antigen class II (HLA-II) level of the allogeneic cells. Therefore, OrCel ${ }^{\circledR}$ skin equivalent is well tolerated by the recipient after grafting into wound bed. The company reported in both clinical trial and commercial experience no clinical signs of tissue rejection using the cryopreserved OrCel $\AA$ product. Resorption appears to take place gradually, with no remnants of the donor cells or matrix being detectable by 2 weeks of posttreatment. Their working hypothesis is that extracellular secretion of cytokines and growth factors by the living cells in OrCel $\AA$ is the major factor for accelerating wound healing.

\subsection{Bioprinting of Skin}

The use of three-dimensional (3D) bioprinting has emerged as a flexible tool in regenerative medicine to bioengineer skin substitutes. There are many kinds of bioprinting technologies, but the four more commonly used are inkjet-based printing, extrusion-based printing, laser-assisted printing, and digital light processing (DLP)-based printing - dynamic optical projection stereolithography (DOPsL). Cell viability can be affected by several factors, including bioprinting technique used.

Jorcano laboratory has developed one bioprinter prototype able to print skin cells, soluble factors, and biomaterials in a desired pattern with the help of highprecision Cartesian robots. The printing skin mimics the structural and molecular structure of the human skin [3]. It is the first functional printer to be introduced to the marketplace. To date, there is no allogeneic 3D printed skin used in patients, but this technology raised great hopes for the treatment of scar in the future.

\subsection{Injections of Mesenchymal Stromal Cells (MSCs) for Skin Regeneration}

MSCs were known to contribute to skin regeneration and to accelerate cutaneous wound healing. MSCs were first isolated from bone marrow in the 1970s by their ability to adhere, proliferate, and develop on a plastic surface, displaying fibroblastic morphology. MSCs are multipotent adult progenitor cells that can differentiate to lineages of mesenchymal cells, including osteoblasts, chondroblasts, and adipocytes. These can be isolated from various adult or perinatal tissues such as adipose tissue or umbilical cord. MSCs have shown positive therapeutic effects in many tissue repair situations 
through the secretion of trophic factors. In addition, allogeneic MSCs are well tolerated after injections due to their immune-modulating effects [4].

Many studies have demonstrated that MSCs exhibit a number of trophic functions to enhance skin regeneration, such as promoting angiogenesis, modulating the inflammatory response, and limiting tissue fibrosis [5]. In in vivo studies, these cells have been used successfully to limit scar formation. Transplanted allogeneic or xenogeneic MSCs transiently survive in the implantation site; their therapeutic potential in wound healing is associated with their secretion of trophic effects on resident cells. One of these in vivo studies using a rabbit model showed that intradermal injection of MSCs can regulate inflammation and prevent the formation of hypertrophic scars. The MSCs underwent apoptosis rapidly in the injected site, between 24 and 72 hours postinjection. They demonstrated that apoptosis has an important role in the activation of the inflammatory regulatory abilities of MSCs through TNF-alpha stimulated protein 6 (TSG-6) [6].

An in vivo study showed the efficacy of MSCs and dermal fibroblasts combined to minimize skin hypertrophic scarring [7]. They showed that transplanted xenogeneic MSCs influenced positively fibroblast proliferation, migration, and extracellular matrix deposition and reduced inflammation following wounding. This effect was superior to MSC or fibroblast transplantation alone. This study suggests that MSCs, even if eventually rejected quickly after injection, transplanted with fibroblasts normalize matrix regeneration during wound healing. This promising study provides insight into allogeneic cell therapies as a viable method for antifibrotic treatment and demonstrates that even transiently engrafted cells can have a long-term impact via matrix modulation and effect on other tissue cells.

One of the first randomized, controlled clinical trial will study the safety and efficacy of MSCs in skin scar for the treatment of Cesarean section [8]. Eligible patients received transdermal hydrogel MSCs once a day for six consecutive days. Their outcomes should be available soon ( $\triangleright$ ClinicalTrials.gov, NCT02772289).

\subsection{Promising Embryonic(-Like) Stem Cells Therapy for Scar Treatment}

Embryonic stem cells (ESCs) and induced pluripotent stem cells (iPSCs) are defined as pluripotent cells able to self-renew. In the field of skin, those stem cells showed some promising results regarding fibrosis care.

Many in vitro and/or in vivo studies are ongoing on embryonic stem cells and induced pluripotent stem cells
(iPSC) as potentially promising in scar management [9]. As fetal cells, ESCs are thought to possess antifibrotic ability. An in vitro study showed the capacity of ESCderived macrophages to secrete scarless-like secretome to regulate the altered keloid niche and reverse the profibrotic phenotype of keloid fibroblasts [10]. Because iPSCs are similar to ESCs in many features, they have been evaluated in scar tissue repair. An in vitro recent study documented that iPSC-conditioned medium may efficiently suppress hypertrophic scar fibroblast activation [11].

\subsection{Conclusion/Discussion}

The allogeneic cell therapy for scar management shows many advantages: large prefabrication, cryopreservation for instant use, and repeated applications. They also allow the use of fetal cells such as embryonic stem cells. Furthermore, they are applicable for genetic skin disease inducing wound healing without genetic modifications.

Most of current and emerging therapeutics for scar management are using allogeneic fibroblasts and keratinocytes as epidermal sheet, dermal substitute, or skin equivalent. The immune rejection of these adult cells is commonly reported, mostly shown for allogeneic keratinocytes due to different HLA expression and cytokine production. Fetal cells are of particular interest for skin repair due to the high expansion ability, low immunogenicity, and intense secretion of bioactive factors. However, the main cellular effect seems in promoting wound healing through secretion of endogenous and exogenous factors rather than cell survival.

Regarding the viability of allogeneic cells, most of the studies on the literature agree on the fact that allogeneic cells do not survive for a long time after transplantation. But most of their therapeutic potential seems to be based on their secretion of trophic factors such as growth factors, cytokines, and extracellular vesicles at least for MSC therapy and also for dermal fibroblasts therapy. Extracellular vesicles (exosomes, microvesicles, and apoptotic bodies) are secreted by most cells of the organism. These extracellular vesicles are of growing interest among investigators, specially from MSCs across multiple fields, including dermatology as a drug [12]. As MSCs or stem cells, extracellular vesicles demonstrate immunomodulatory properties, accelerate skin cell migration and proliferation, control wound scarring, and improve angiogenesis. Several clinical trials should appear in the future years testing the safety and the efficacy of stem cells and derived products for skin scar treatment. 


\section{References}

1. Marshall CD, Hu MS, Leavitt T, Barnes LA, Lorenz HP, Longaker MT. Cutaneous scarring: basic science, current treatments, and future directions. Adv Wound Care. 2016;7(2):29-45.

2. Shpichka A, Butnaru D, Bezrukov EA, Sukhanov RB, Atala A, Burdukovskii V, et al. Skin tissue regeneration for burn injury. Stem Cell Res Ther. 2019;10(1):1-16.

3. Cubo N, Velasco D, Jorcano JL, Garcia M, del Cañizo JF. 3D bioprinting of functional human skin: production and in vivo analysis. Biofabrication. 2016;9(1):015006.

4. Najar M, Raicevic G, Fayyad-Kazan H, Bron D, Toungouz M, Lagneaux L. Mesenchymal stromal cells and immunomodulation: a gathering of regulatory immune cells. Cytotherapy [Internet]. 2016;18(2):160-71.. Available from: https://doi. org/10.1016/j.jcyt.2015.10.011

5. Jackson WM, Nesti LJ, Tuan RS. Mesenchymal stem cell therapy for attenuation of scar formation during wound healing. Stem Cell Res Ther. 2012;3(3):20.

6. Liu S, Jiang L, Li H, Shi H, Luo H, Zhang Y, et al. Mesenchymal stem cells prevent hypertrophic scar formation via inflammatory regulation when undergoing apoptosis. J Invest Dermatol
[Internet]. 2014;134(10):2648-57.. Available from: https://doi. org/10.1038/jid.2014.169

7. Yates CC, Rodrigues M, Nuschke A, Johnson ZI, Whaley D, Stolz D, et al. Multipotent stromal cells/mesenchymal stem cells and fibroblasts combine to minimize skin hypertrophic scarring. Stem Cell Res Ther. 2017;8(1):1-13.

8. Fan D, Xia Q, Wu S, Ye S, Liu L, Wang W, et al. Mesenchymal stem cells in the treatment of cesarean section skin scars: study protocol for a randomized, controlled trial. Trials. 2018;19(1): 4-11.

9. Li Q, Zhang C, Fu X. Will stem cells bring hope to pathological skin scar treatment? Cytotherapy [Internet]. 2016;18(8):943-56.. Available from: https://doi.org/10.1016/j.jcyt.2016.05.008

10. Dreymueller D, Denecke B, Ludwig A, Jahnen-Dechent W. Embryonic stem cell-derived M2-like macrophages delay cutaneous wound healing. Wound Repair Regen. 2013;21(1):44-54.

11. Ren Y, Deng CL, Wan WD, Zheng JH, Mao GY, Yang SL. Suppressive effects of induced pluripotent stem cell-conditioned medium on in vitro hypertrophic scarring fibroblast activation. Mol Med Rep. 2015;11(4):2471-6.

12. Ferreira ADF, Gomes DA. Stem cell extracellular vesicles in skin repair. Bioengineering. 2018;6(1):4.

Open Access This chapter is licensed under the terms of the Creative Commons Attribution 4.0 International License (http://creativecommons. org/licenses/by/4.0/), which permits use, sharing, adaptation, distribution and reproduction in any medium or format, as long as you give appropriate credit to the original author(s) and the source, provide a link to the Creative Commons license and indicate if changes were made.

The images or other third party material in this chapter are included in the chapter's Creative Commons license, unless indicated otherwise in a credit line to the material. If material is not included in the chapter's Creative Commons license and your intended use is not permitted by statutory regulation or exceeds the permitted use, you will need to obtain permission directly from the copyright holder. 